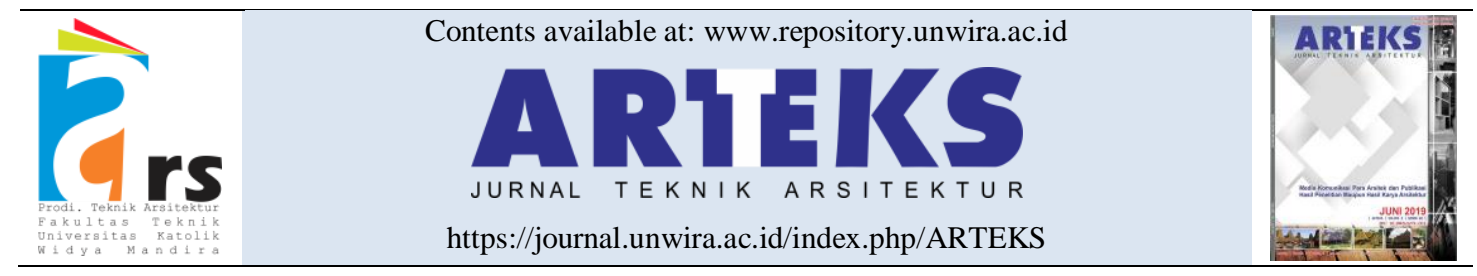

Research paper

doi: $10.30822 /$ arteks.v5i3.465

\title{
Modern architecture in Indonesia: A genealogy study
}

\author{
Johannes Adiyanto \\ Architecture Engineering Department, Faculty of Engineering, Universitas Sriwijaya \\ Jl. Raya Palembang-Prabumulih KM. 32, Inderalaya, Ogan Komering Ilir \\ South Sumatera, Indonesia
}

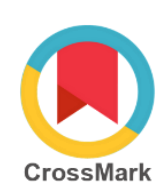

\begin{tabular}{l}
\hline ARTICLE INFO \\
\hline Article history: \\
Received April 18, 2020 \\
Received in revised form April 27, 2020 \\
Accepted July 26, 2020 \\
Available online December 01, 2020
\end{tabular}

Keywords:

Adaptation

Formal architecture education

Indonesian

Politics

Synchronous-diachronic

*Corresponding author: Johannes Adiyanto Architecture Engineering Department, Faculty of Engineering, Universitas Sriwijaya, Indonesia

Email: johannesadiyanto@ft.unsri.ac.id

ORCID: https://orcid.org/0000-0002-22951144

\section{Introduction}

The word genealogy is derived from the Ancient Latin genealogia which means tracing family lineages ('Genealogy', n.d.). In historical research, the genealogical approach draws history and also 'write' something 'new'. In Foucault's thinking strategy, it focuses on the historical outlines related to the phenomena influencing and coinciding with the 'lineage' (Tamboukou 1999).

The existence of architecture in Indonesia, especially the modern aspects, is the basis of this research. The previous study conducted by Hidayatun examined the identity of Indonesian architecture through the regionalism approach (Hidayatun, Prijotomo, and Rachmawati 2014a) while Martokusumo showed its development from a local context is the foundation for the modern architecture adopted from Europe. Another research considered it as an experimental effort to obtain innovation in architecture (Martokusumo 2007).

Hidayatun and Martokusuma have conducted a pilot discussion on the existence of modern architecture in Indonesia and they both argued it was created by adapting European architecture into the local environment, especially the humid tropical climate.

It is also important to understand the term "modern" which is derived from the Latin modo which means 'just now' ('Modern', n.d.). Oxford dictionary defines it as 'existing in the present or recent times, or using or based on recently 
developed ideas, methods, or styles ('Modern', n.d.).'

This meaning was further emphasized by Widodo in the Asian context to be a process rather than a product (Widodo 2007). This paper questioned this opinion by trying to determine the 'beginning' of modern architecture in Indonesia. It also aimed to determine if it is 'only' on adaptation according to Hidayatun's opinion and also focused on contemporary architecture over geometrical discussions in response to Martokusumo's challenge.

\section{Method}

The present paper is a historical study involving the use of the Foucault genealogy approach with a synchronous-diachronic method adapted from linguistic theory, especially with reference to the Ferdinand de Saussure. Moreover, the synchronic approach analyzes the language similarities and differences at specific time points by focusing on structural features and characteristics. It also uses phonological, morphological, syntactic explanations, as well as semantic and pragmatic aspects. Meanwhile, the diachronic approach investigates the development of language in a certain period by paying attention to the affinity between language and sound transmutation historically, and by striving for the reconstruction of major languages. They both describe the genealogical relation of language (Hämäläinen 2014).

In the architectural context, the synchronic approach according to Hidayatun refers to the meaning associated with the phenomena extending to certain spaces in an indefinite period. Meanwhile, the diachronic is related to time or process in history (Hidayatun, Prijotomo, and Rachmawati 2014b). This means synchronization is more concerned with structure and function - in this case, architecture - with the diachronic approach emphasizing on the dimensions of time in the form of process and duration (Adiyanto 2018).

According to Widodo, the four periods of modernization in Indonesia include (1) the protomodern covering 1500-1600 and characterized by the entrance of traders from China, India, Arab, and Persia, (2) early-modern covering 1600-1800 with the arrival of the European traders, (3) newmodern covering1800-1940 which started with the VOC bankruptcy and the political system up to the early masses of World War II, and (4) the modern-present which spans between 1940 1970 (Widodo 2007).

\section{Result and discussion}

\section{Proto-modern period (1500-1600)}

The following scheme was conveyed in Widodo's doctoral research's abstract (Figure 1) (Widodo 1996):

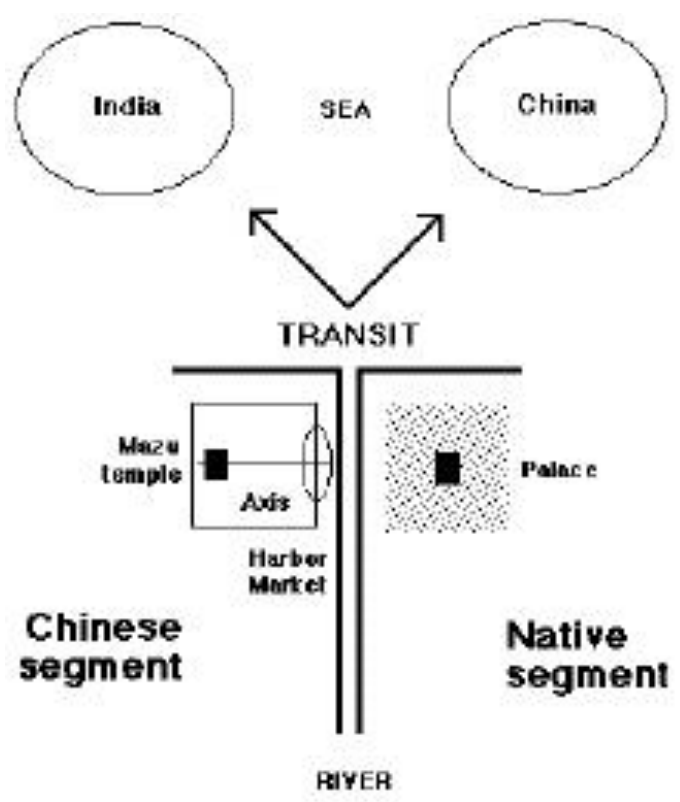

Figure 1. The common entrepot model in Southeast Asia

Source: (Widodo 1996)

The scheme above shows the 'renewal' process in the built environment, especially in the coastal areas or the harbor which is the port functioning also as a market. It is also considered as the 'embryo' of modern residential habitats which was later developed as port cities.

\section{Early modern period (1600-1800)}

This period started with the entrance of European traders into the archipelago after the Arab and Persians. At this time, several modern ports have been developed such as Malacca and Banten which are later upgraded like Batavia and Semarang. Moreover, the construction of residential buildings started tended to be similar to those found in Europe. Some of the structures observed include church facilities, open spaces, 
administrative offices, military buildings, and warehouses in a sturdy 'fortress' - which resembles a fortress town in medieval times in Europe (Figure 2) (Widodo 1996).

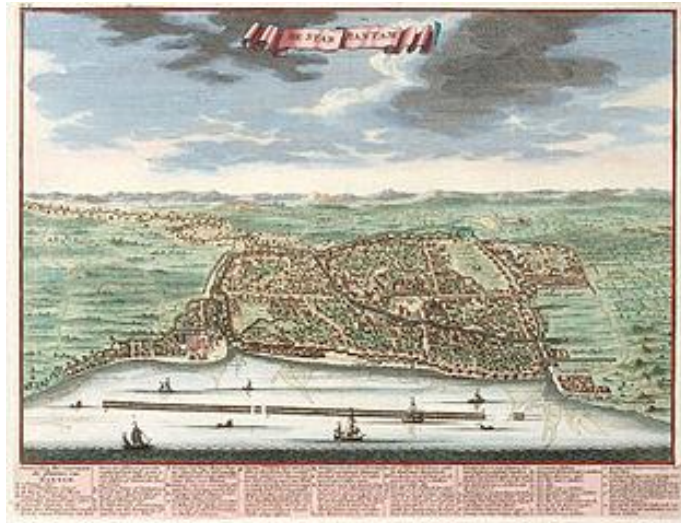

Figure 2. Sketch of Banten in 1724

Source: (Valentijn 2010)

In the previous period, both indigenous and immigrant traders from China, Arabia, and Persia had an equal position and no clear separation of residence. However, the early modern period was characterized by increasingly apparent division and the European residence was observed to have exclusivity. The occupancy is closed and limited only to compatriots and the architectural form was also discovered to be 'copying' the European residential designs, complete with supporting facilities built in a restricted area.

\section{New-modern (1800-1940)}

The governance system of Indonesia changed after the golden age of the VOC. The basic life contract between European societies or the Kingdom of the Netherlands with local communities was no longer based on trade cooperation but rather on colonialism. This led the Netherlands to 'create' a separate government known as the Dutch East Indies or often also called the Hindia Belanda.

In 1806, the Kingdom of the Netherlands was, however, conquered by the Kingdom of France, and the Dutch East Indies was under the command of Herman William Daendels.



Figure 3. Waterloo square in Batavia, 1842

Source: (Royal Netherlands Institute 1842)

Even though Daendels only served in the Dutch East Indies from 1808-1811, Handinoto reported the significant changes in government, especially in physical development. For example, a road was constructed from Anyer to Panarukan while a French aristocratic style of building was also initiated which was later known as Empire Style. Figure 3 shows the construction was not made on the port area but rather in the inland towards the south in an area considered to be the forerunner to the center of the current Jakarta. The change was due to the health and hygiene problems observed to be prevailing in the old Batavia port area (Handinoto 2008).

The Empire Style of the building was adapted to local conditions and this led to the emergence of Indies Empire style in line with the development of Indies culture which is a combination of both European and local culture as well as a result of mixed marriages between European men and indigenous women.

The building style formulated was, however, reported by Moojen and Berlage to have been criticized to be a low-quality form of architecture (Handinoto 1994).

The architectural approach was also observed to be a way to integrate European architecture into the tropical climate (Widodo 2007). This was the beginning of the conflicts between the architects of the modern architecture movement with those interested in local ones known as the regionalism movement.

The policy of forced cultivated was adopted in 1830 by Johannes van de Bosch and this period was later known as the era of economic liberation due to the issuance of the Agrarian and Sugar Laws of 1870. The Dutch East Indies land became 
a plantation land while the commodities produced were sold properly in Europe. The focus was also reported to have shifted on local products such as spices to plants needed by Europeans such as coffee, sugar cane, tea, and palm tree. The economic liberalization provided foreign and local investors the opportunity to invest in profitable commodities. This, therefore, was the beginning of the popularity of some local businessmen such as Oei Tiong Ham known as the sugar king and the leaders of the sugar kingdoms such as Mangkunegara IV controlling the Colomadu Sugar Factory at the time (Mangkunegaran 2017).

The physical development in the Dutch East Indies led to industrial functions classification to support the plantation sector as observed with the construction of factories, train stations, steam shipyards, and others. This industrial era came with the introduction of the steam engine.

The period that followed was due to the development of European socialization which required the services of educated workers with more skills compared to strength for several jobs. This was also in line with the political policy of the Kingdom of the Netherlands which was later known as the Ethical Politics. Moreover, the Trias van Deventer was reported to have consisted of 3 things including irrigation improvement, immigration inviting residents to transmigrate, and education ('Politik Etis' 2020).

This paper focuses on the third area, education and its types are based on ethnic groups as observed in European (Dutch), Chinesedescendant, and selected indigenous communities ('Pendidikan Masa Kolonial', n.d.).

Technische Hoogeschool te Bandoeng or TH Bandung which is now known as Institute of Technology Bandung (ITB) was established on July 3, 1920, with the curriculum of TH Delft modified for the engineering college. In the early days, no professor was reported to have focused on architecture. Meanwhile, Prof. Richard Leonard Arnold Schoemaker, younger brother of Charles Prosper Wolff Schoemaker, is a professor in the building field and was appointed as an extraordinary professor in the History of Architecture and Decorative Arts, Specifications and Estimates, and Urban Planning on January 1, 1922 ('Technische Hoogeschool Te Bandoeng' 2020).

The interesting thing about TH Bandung is that the campus design was created by Maclaine Pont by adopting the Minangkabau roof (Verma
2017) but Wolff Schoemaker was a modernist with inclination to the architectural formations developed in Europe (Rachmi and Budi 2017). Meanwhile, his works after he returned from America in 1918 were greatly influenced by Frank Lloyd Wright, and the peculiarities of his works after 1930 such as Villa Isola in Bandung was discovered in an Art Deco style building (Handinoto 2010).

Another tug of war between modern European and local architect figures was observed and this required discussing the conflicts between Wolff Schoemaker and Maclaine Pont separately. It is important to note that Wolff Schoemaker had the opportunity to become a professor at $\mathrm{TH}$ Bandung, while Maclaine Pont did not an even though he was offered the role after World War II, he was unable to accept it due to health reasons (Handinoto 2010). This became a big differentiator in subsequent architectural developments.

\section{Modern-present period (1940-1970)}

The Japanese era was not discussed in this paper since no architectural influence was explored in the period and this led to the focus on 1959 and beyond.

Soekarno was recorded to have made an 'improvement' on the face of Jakarta after obtaining certainty of war reparations funds from Japan in 1958 as a consequence of the Francisco Agreement which was effective on April 28, 1952 (Adhani 2010). This improvement was supported by the non-aligned political approach adopted by Sukarno by involving the members of the newly independent countries after World War II and several others. It is also possible to compare the Jakarta's urban planning improvements to the city of Brasilia constructed in 1956-1961 and initiated by Juscelino Kubitschek ('Juscelino Kubitschek' 2020) and the city of Chandigarh completed in 1960 and initiated by Jawaharlal Nehru ('Chandigarh' 2020). Soekarno, like other world leaders, used architecture as a 'stage' to demonstrate the ability of the newly independent nation (Figure 4) (Ardhiati 2013). 


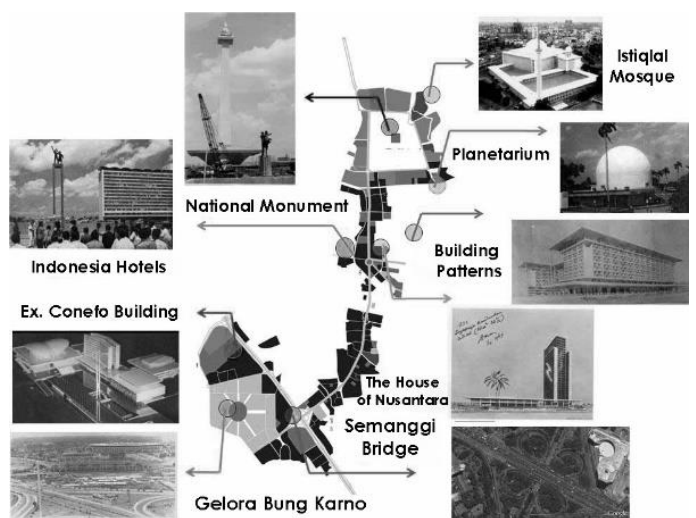

Figure 4. Project initiated by Sukarno in the main corridor of Jakarta

Source: (Ardhiati 2013)

Ardhiati's report on Sukarno's statement that the sporting event, Gelora Bung Karno, was a means to show the nation's ability was confirmed by Hartanto. It was observed as one of the plants to ensure nation-building to ensure other nations acknowledge Indonesian independence (Hartanto 2018).

Modern architectural approaches, especially international styles based on local concepts, were the choices made by Sukarno to obtain recognition from other countries in the world (Ardhiati 2013). Sukarno studied architecture at TH Bandung and his professor was Leonard Arnold Schoemaker with basic knowledge in modern Dutch buildings. The decision was influenced by his favorite architect, F. Silaban, with expertise in modern European architecture (Sopandi 2017). Moreover, the physical buildings constructed during the repair period of Jakarta from 1959-1965 were assisted by the United States and the Soviet Union and this led to the construction of modern buildings with reinforced concrete and steel materials.

The formation of the professional architect association on September 16, 1959, was also observed to have aided the use of modern architecture in Indonesia. This was associated with the establishment of the IAI by 3 main figures of the era including Silaban, Liem Bwan Tjie, and Soejodi. The three of them gained knowledge of modern architecture in their respective ways and were also supported by 18 young architect graduates from TH Bandung that practiced professionally and became educators at several universities and institutes in Indonesia ('Ikatan Arsitek Indonesia' 2020). For example, Suhartono Soesilo, the son of M. Soesilo, that also participated in the formation of IAI became a lecturer and founder of the architecture department at UNPAR (Sosilo 1986).

This means modern architecture is not only spread in the physical form through buildings but also as a basis for architectural education in Indonesia.

This signifies the end of the chronological exploration of modern architecture.

\section{Discussion}

The existence of the Schoemaker brothers in TH Bandung seems to be an important point in the development and dissemination of modern architecture in Indonesia. This could have been colored more had it been Maclaine Pont also acted as a teacher but not only as a designer. Meanwhile, his life journey which involved being tutored by Berlage and working in Trowulan to design the roof of the Poh Sarang church made a 'differentiator' which was quite sharp compared to Wolff Schoemaker's work whose life was colored with experience in the military. There is, however, the need to explore the appeals between Schoemaker and Pont approaches further. In several works, they were both reported to be equally influenced by the Amsterdam Style approach (Hartono and Handinoto 2007) but, on several occasions, there is a debate on their relation to the context (Martokusumo 2007).

Another perspective is those associated with indigenous thinkers such as Manguwijaya, Josef Prijotomo, and Setiadi Sopandi. Manguwijaya studied at ITB and later at Rheinisch Westfaelische Technische Hochschule in Aachen, Germany ('Y. B. Mangunwijaya' 2020), and this education channel confirms his inclination to the modern architectural approach. However, Wastu Citra's book showed Mangunwijaya referred to the proto-modern era with the county's architecture believed to have originated from India and China in line with Maclaine Pont's thought in several respects.

Josef Prijotomo, also well-known for his Nusantaranya Architecture approach, offered thoughts comparable to Berlage's statement on the sensitivity of local architecture as a basis for new archipelago architecture (Martokusumo 2007). Moreover, Van Romondt's believed those with the ability to 'find' and 'create' new architecture are the natives (Romondt 1954).

Setiadi Sopandi, an architectural history researcher, described F. Silaban's thoughts that there was no need to copy traditional architectural 
forms but instead sought to root the idea of tropicality (Sopandi 2017). This submission is in line with the thoughts and concepts of Soekarno's nation-building process.

\section{Conclusion}

The chronological exploration and understanding of the content of 'modern architecture' shows the 'modern' has inevitably become the 'identity' attached to the development of architecture in Indonesia. It is important to note the "modern" concept does not refer to the kind of movement observed in Europe, especially in the Bauhaus (read (Swadiansa 2020)) but as a process of change and adaptation.

The political influence of authorities was also found to be a significant indicator in developing modern architecture as observed in the Daendels and Sukarno periods.

The analysis further showed the 'modern architecture' has been in existence since the arrival of foreign nations. At some point, it was constructed as a way to adapt Europe/American style to the climate and socio-geographical conditions of the country. Therefore, modern architecture in Indonesia is 'different' from those found in Europe or America.

\section{References}

Adhani, Rachmat. 2010. 'Pampasan Dan Kejahatan Perang Jepang Terhadap Indonesia'. The Global Review. 2010. http://theglobal-

review.com/lama/content_detail.php?lang=en \&id=3031\&type=4\#.X1SzrnkzbIV.

Adiyanto, Johannes. 2018. 'Mencari DNA Arsitektur Di Nusantara'. In Prosiding Seminar Peng-Konteks-an Arsitektur Nusantara, B015-22. Surabaya: Ikatan Peneliti Lingkungan Binaan Indonesia. https://doi.org/10.32315/sem.2.b015.

Ardhiati, Yuke. 2013. 'The Idea of "Architecture Stage": A Non-Material Architecture Theory'. Journal of Civil Engineering and Architecture
$7 \quad$ (10). https://doi.org/10.17265/19347359/2013.10.015.

'Chandigarh'. 2020. Wikipedia Ensiklodia Bebas. 2020. https://en.wikipedia.org/wiki/Chandigarh.

'Genealogy'. n.d. Online Etymology Dictionary. https://www.etymonline.com/search?q=genea $\log y$.

Hämäläinen, Juha. 2014. 'Comparative Research in Social Work: Methodological Considerations Using the "DiachronicSynchronic" Distinction in Linguistics'. European Journal of Social Work 17 (2): 192205.

https://doi.org/10.1080/13691457.2013.7773 33.

Handinoto. 1994. "Indische Empire Style” Gaya Arsitektur "Tempo Doeloe" Yang Sekarang Sudah Mulai Punah'. DIMENSI: Journal of Architecture and Built Environment 20. http://fportfolio.petra.ac.id/user_files/81005/IESTYLE.pdf.

- 2008. 'Deandels Dan Perkembangan Arsitektur Di Hindia Belanda Abad 19'. DIMENSI: Journal of Architecture and Built Environment $36 \quad$ (1): 43-53. http://puslit2.petra.ac.id/ejournal/index.php/a rs/article/view/16973.

—. 2010. 'Studi Perbandingan Karya 3 Orang Arsitek Belanda Kelahiran Jawa Di Indonesia'. In Arsitektur Dan Kota-Kota Di Jawa Pada Masa Kolonial, 59-84. Yogyakarta: Graha Ilmu. http://fportfolio.petra.ac.id/user_files/81005/ARSITEK BELANDA.pdf.

Hartanto, Robin. 2018. 'The Shape of Sport Diplomacy: Gelora Bung Karno, Jakarta and the Fourth Asian Games'. In MASEANa Project 2017: Modern Living in Southeast Asia, 26-29. Tokyo: Tokyo: DOCOMOMO JAPAN ( mASEANa Project Committee). http://www.maseana.iis.u-

tokyo.ac.jp/assets/maseana-2017_web.pdf.

Hartono, Samuel, and Handinoto Handinoto. 2007. "The Amsterdam School" Dan Perkembangan Arsitektur Kolonial Di Hindia Belanda Antara 1915-1940'. DIMENSI (Journal of Architecture and Built Environment) $\quad 35 \quad$ (1): 46-58. https://doi.org/10.9744/dimensi.35.1.46-58.

Hidayatun, Maria I., Josef Prijotomo, and Murni Rachmawati. 2014a. 'Arsitektur Nusantara Sebagai Dasar Pembentuk Regionalisme Arsitektur Indonesia'. In Transformasi Nilai- 
Nilai Tradisional Dalam Arsitektur Masa Kini, 1-9. Surabaya: Petra Christian University.

http://repository.petra.ac.id/17366/1/Publikas i1_85012_2286.pdf.

Hidayatun, Maria I, Josef Prijotomo, and Murni Rachmawati. 2014b. 'Arsitektur Di Indonesia Dalam Perkembangan Jaman, Sebuah Gagasan Untuk Jati Diri Arsitektur Di Indonesia'. In Ruang \& Tempat Dalam Latar Indonesia. Yogyakarta: Lembaga Sejarah Arsitektur Indonesia dan Fakultas Arsitektur dan Desain Universitas Kristen Duta Wacana. http://repository.petra.ac.id/16632/1/Publikas i1_85012_1436.pdf.

'Ikatan Arsitek Indonesia'. 2020. Wikipedia Ensiklodia 2020. https://id.wikipedia.org/wiki/Ikatan_Arsitek_ Indonesia.

'Juscelino Kubitschek'. 2020. Wikipedia Ensiklodia 2020. https://en.wikipedia.org/wiki/Juscelino_Kubit schek.

Mangkunegaran. 2017. 'Sejarah Pabrik Gula Colomadu: Awal Pembangunan Pabrik Gula Colomadu'. Puro Mangkunegaran. 2017. https://puromangkunegaran.com/sejarahpabrik-gula-colomadu-awal-pembangunanpabrik-gula-colomadu/.

Martokusumo, Widjaja. 2007. 'Arsitektur Kontemporer Indonesia, Perjalanan Menuju Pencerahan'. In Kajian Arsitektur Moderen. Banten: Dinas Pekerjaan Umum Pemerintah Provinsi Banten, Serang. https://d1wqtxts1xzle7.cloudfront.net/348419 05/arsitektur-kontemporer-indonesiaperjalanan-menujupencerahan.pdf?1411469287=\&responsecontentdisposition=inline $\% 3 \mathrm{~B}+$ filename $\% 3 \mathrm{DArsitek}$ tur_Modern_Indonesi1.pdf\&Expires=159607 2891\&Signature $=$ G $\sim$ IrFZaSROj7s0NsgYU.

'Modern'. n.d. Online Etymology Dictionary. https://www.etymonline.com/search?q=mode rn.

- 'Modern'. n.d. Cambridge Dictionary. https://dictionary.cambridge.org/dictionary/e nglish/modern.

'Pendidikan Masa Kolonial'. n.d. Museum Pendidikan Nasional UPI. http://museumpendidikannasional.upi.edu/ind ex.php/pendidikan-masa-kolonial.

'Politik Etis'. 2020. Wikipedia Ensiklodia Bebas. 2020. https://id.wikipedia.org/wiki/Politik_Etis.

Rachmi, Raudina, and Bambang Setia Budi. 2017. 'Identifikasi Elemen Arsitektur Khas C.P. Wolff Schoemaker Dalam Arsitektur Masjid Raya Cipaganti'. In Seminar Ikatan Peneliti Lingkungan Binaan Indonesia, A145-52. Ikatan Peneliti Lingkungan Binaan Indonesia. https://doi.org/10.32315/sem.1.a145.

Romondt, V. R. Van. 1954. 'Menuju Kesuatu Arsitektur Indonesia'. Bandung. http://omahlibrary.com/exhibition/2018/05/menuju-kesuatu-arsitektur-indonesia-ir-v-van-romondt/.

Royal Netherlands Institute. 1842. 'Waterlooplein in Batavia / Waterloo Square in Batavia / Lapangan Waterloo Di Batavia, 1842'. Flickr. 1842. https://www.flickr.com/photos/kitlvcollection s/5433457504/.

Sopandi, Setiadi. 2017. Friedrich Silaban. Jakarta: Gramedia Pustaka Utama.

Sosilo, Moh. 1986. Perjalanan Hidup H. Moh. Soesilo: Architect \& Town Planner.

Swadiansa, Eka. 2020. Ornament Is Rhyme. I. Jakarta: RAW Architecture.

Tamboukou, Maria. 1999. 'Writing Genealogies: An Exploration of Foucault's Strategies for Doing Research'. Discourse: Studies in the Cultural Politics of Education 20 (2): 201-17. https://doi.org/10.1080/0159630990200202.

'Technische Hoogeschool Te Bandoeng'. 2020. Wikipedia Ensiklodia Bebas. 2020. https://id.wikipedia.org/wiki/Technische_Ho ogeschool_te_Bandoeng.

Valentijn, François. 2010. 'Painting of Banten, in 1694'. Wikipedia Ensiklodia Bebas. 2010. https://en.wikipedia.org/wiki/Banten\#/media/ File:Banten-city-Java-1724.jpg.

Verma, Guino. 2017. 'Kajian Pemikiran Akulturasi Henry Maclaine Pont Pada Elemen Desain Interior Aula Timur Dan Aula Barat ITB'. In Seminar Ikatan Peneliti Lingkungan Binaan Indonesia, C129-36. Ikatan Peneliti Lingkungan Binaan Indonesia. https://doi.org/10.32315/sem.1.c129.

Widodo, Johannes. 1996. The Urban History of the Southeast Asian Coastal Cities: (Particularly from 14th Century Until Mid20th Century). Tokyo: University of Tokyo. 
https://www.iis.u-

tokyo.ac.jp/ fujimori/myhomepage/phd.html. . 2007. 'Arsitektur Indonesia Modern:

Transplantasi, Adaptasi, Akomodasi, Dan Hibridisasi’. In Masa Lalu Dalam Masa Kini, edited by Peter J.M. Nas, 17-24. Jakarta: Gramedia Pustaka Utama.

'Y. B. Mangunwijaya'. 2020. Wikipedia Ensiklodia Bebas. 2020. https://id.wikipedia.org/wiki/Y.B._Mangunw ijaya. 